\title{
Analisis Sumber Daya Manusia Pendidikan Tinggi
}

\author{
Ida Kintamani Dewi Hermawan \\ Email idakintamani@yahoo.com
}

\begin{abstract}
Abstrak: Tujuan analisis SDM PT adalah untuk memahami profil SDM PT, mutu SDM PT, dan menentukan mutu PT dengan menggunakan data tahun 2009/2010. Metode yang digunakan dalam analisis ini adalah studi dokumentasi dan survai. Selain itu, digunakan indikator kinerja utama (IKU) dari Rencana Strategi Pendidikan tahun 2010-2014 untuk menilai mutu PT. Hasilnya menunjukkan bahwa walaupun lembaga PT Swasta sebesar 97,24\% dari lembaga PT yang ada, namun mahasiswanya hanya sebesar 58,39\% dan dosennya sebesar $71,83 \%$. Berdasarkan 7 indikator, kelayakan dosen mengajar hanya $37,65 \%$, dosen tetap sebesar $67,82 \%$, dosen jabatan guru besar sebesar 3,59\%, dosen senior sebesar $19,84 \%$, dan tenaga kependidikan kebanyakan lulusan SM sebesar 34,82\%. Berdasarkan 5 indikator komposit yang dipilih maka mutu PT hanya sebesar 49,85 berarti kurang dari separuh. Dengan melihat hasil seperti ini maka disarankan agar dilakukan penelitian lanjutan mengenai pendataan PT khususnya dosen dengan semua rinciannya dan apakah indikator komposit yang digunakan telah sesuai untuk mengukur mutu PT.
\end{abstract}

Kata kunci: analisis, sumber daya manusia, pendidikan tinggi, data dan indikator, mutu pendidikan.

\begin{abstract}
The purpose of this analysis is to understand the Higher Education (HE) Human Resources profile and quality, and determine the quality of HE by using the 2009/2010 data. The method used in this analysis is the documentation study and the survey. In addition, the use of key performance indicators from Education Strategic Plan 2010-2014 to assess the quality of HE. Results showed that although private institutions have reached $97.24 \%$ of $\mathrm{HE}$, it only has $58.39 \%$ of the students and $71.83 \%$ lecturers. Based on 7 indicators, feasibility of lecturers to teach only $37.65 \%$, full-time professors $67.82 \%$, lecturers professors $3.59 \%$, senior lecturer $19.84 \%$, and most education personnel are high school graduated which is $34.82 \%$. Based on the selected five composite indicators, the quality of PT is only 49.85 means that less than half. By looking at the results, they are advised to conduct further research regarding collection of data about the $\mathrm{HE}$, especially teachers with all the details and whether the composite indicators used are appropriate to measure the quality of $\mathrm{HE}$.
\end{abstract}

Key Words: analysis, human resource, higher education, data and indicator, education quality.

\section{Pendahuluan}

Program pembangunan sektor pendidikan adalah sesuai dengan Undang-Undang Nomor 20, Tahun 2003 tentang Sistem Pendidikan Nasional (UU No. 20/2003). (Depdiknas, 2002a). Sistem pendidikan nasional tersebut harus mampu menjamin pemerataan kesempatan pendidikan, peningkatan mutu serta relevansi dan efisiensi manajemen pendidikan untuk menghadapi tantangan sesuai dengan tuntutan perubahan kehidupan lokal, nasional maupun global. Untuk itu, perlu dilakukan pembaharuan pendidikan secara terencana, terarah, dan berkesinambungan.

Pembaharuan pendidikan dilaksanakan antara lain untuk meningkatkan mutu pendidikan. Dalam rangka meningkatkan mutu pendidikan salah satu faktor penting yang pada saat sekarang masih dianggap cukup mempengaruhi pendidikan adalah keberadaan pendidikan baik dari segi kuantitas maupun kualitas. Pendidik yang bermutu diharapkan dapat mengajar sesuai dengan ketentuan yang berlaku sehingga menghasilkan lulusan yang bermutu. Dari lulusan yang bermutu pada akhirnya dapat meningkatkan mutu pendidikan.

Sampai saat ini masih banyak hambatan dan kendala dalam meningkatkan mutu pendidik karena adanya beberapa permasalahan yang dihadapi, yaitu 1) pengadaan, 2) pengangkatan, 3) penempatan, dan 4) pembinaan pendidik. Selain itu, permasalahan pendidik tidak hanya berkaitan dengan kebutuhan pendidik yang diakibatkan oleh 
pertambahan mahasiswa melainkan juga pembinaan, keahlian profesional, dan kesejahteraan pendidik.

Pemerintah yang dalam hal ini adalah Kemdiknas bertugas untuk meningkatkan mutu pendidik tidak hanya yang sudah mengajar melainkan juga untuk memenuhi kebutuhan pendidik yang sesuai dengan syarat yang diperlukan. Oleh karena itu, perlu diketahui dimensi penting dari pendidik yang dapat disebut bermutu. Berdasarkan kondisi saat sekarang, pendidik yang bermutu dapat dilihat dari beberapa hal, yaitu 1) jumlah pendidik mencukupi, 2) pembinaan karier dan profesional sebagai pendidik, 3) kesejahteraan pendidik, dan 4) persebaran dalam penempatan pendidik sesuai dengan perencanaan kebutuhan pendidik. Tugas pemenuhan kebutuhan pendidik yang bermutu pada butir 1 dan 2 merupakan tantangan bagi Lembaga Pendidikan Tenaga Kependidikan (LPTK) atau institusi yang menghasilkan pendidik dan tenaga kependidikan lainnya, butir 3 perlu mendapatkan perhatian dalam perencanaan dan pembinaan pendidik di masa depan, sedangkan butir 4 akan dapat dipenuhi dengan adanya Undang-Undang Nomor 14, Tahun 2005 tentang Guru dan Dosen (UU No.14/2005). (Depdiknas, 2005).

Pendidik sangat diperlukan oleh pendidikan nasional termasuk pada jenjang pendidikan tinggi yang bertugas mengembangkan sumber daya manusia (SDM) yang bermutu sesuai dengan kebutuhan pembangunan industri. Pengalaman pada masa lalu menunjukkan bahwa kuantitas dan mutu mengajar pendidik dengan ijazah yang dimiliki belum memadai. Berdasarkan Statistik Pendidikan Tinggi, Tahun 2009/2010 masih terdapat dosen pada PT sebesar 87.821 orang $(37,5 \%)$ dari 233.390 orang yang hanya lulusan setingkat Sarjana atau S1 (Kemdiknas, 2010b). Dengan demikian, wajar jika pendidikan selalu mendapat sorotan dari masyarakat karena hasil pendidikan kurang sesuai dengan kebutuhan pembangunan yang salah satu contohnya adalah akibat ketidakmampuan pendidik mengajar karena belum memenuhi syarat sebagai pendidik. Masalah tersebut bisa berakibat masyarakat menjadi ragu terhadap keberadaan LPTK. Oleh karena itu, LPTK seyogyanya selalu meningkatkan kemampuan untuk menghasilkan pendidik yang bermutu dengan kuantitas yang memadai serta sebaran yang sesuai dengan kebutuhan sistem pendidikan.

Keseriusan pemerintah dalam upaya memperbaiki pengelolaan pendidikan khususnya pendidik dan tenaga kependidikan lainnya salah satunya diharapkan mampu menyiapkan program inovatif yang dapat meningkatkan profesionalisme pendidik sesuai dengan UU No. 20/2003 pasal 39 dan 40, yaitu meningkatkan kemampuan merencanakan dan melaksanakan proses pembelajaran dengan menciptakan suasana belajar yang bermakna, menyenangkan, kreatif, dinamis, dan dialogis, menilai hasil pembelajaran, melakukan pembimbingan dan pelatihan serta mempunyai komitmen secara profesional dalam rangka meningkatkan mutu pendidikan. (Depdiknas, 2002a).

Dalam melaksanakan tugas dan fungsinya diperlukan jaringan kerja horizontal maupun vertikal yang harmonis dan responsif oleh semua unit kerja yang terkait dengan upaya peningkatan mutu pendidik dan tenaga kependidikan. Dengan merujuk pada UU No. 20/2003 pasal 11 ayat 1, pemerintah dan pemerintah daerah wajib memberikan layanan dan kemudahan serta menjamin terselenggaranya pendidikan yang bermutu bagi setiap warganegara tanpa diskriminasi. (Depdiknas, 2002a).

Selain itu, implikasi deklarasi guru sebagai profesi oleh Presiden Republik Indonesia pada tanggal 2 Desember 2004 menuntut semua pihak untuk melakukan sinergi melalui mekanisme standarisasi, uji kompetensi, sertifikasi, dan registrasi profesi yang memiliki konsekuensi pada peningkatan kesejahteraan yang layak, sistem penghargaan dan perlindungan profesi yang mampu menjamin masa depannya.

Dalam rangka mendukung upaya tersebut, Pusat Data dan Statistik Pendidikan (PDSP), Kementerian Pendidikan Nasional (Kemdiknas) melaksanakan analisis SDM pendidikan tinggi yang dapat didayagunakan oleh para pengambil keputusan dan perumusan kebijakan dalam rangka perencanaan berbagai kebijakan di bidang pendidikan khususnya pendidik dan tenaga kependidikan pada pendidikan tinggi. 
Dengan menggunakan paparan latar belakang maka permasalahan yang perlu ditelusuri lebih jauh ialah sejauh mana ketersediaan SDM pendidikan pada PT yang merupakan salah satu sumber informasi yang paling dekat dengan objek data sehingga dapat digunakan dalam pengambilan keputusan dan perumusan kebijakan pendidikan yang mendekati kenyataan di lapangan.

Terdapat beberapa asumsi yang perlu diperhatikan dalam kaitan dengan berbagai permasalahan tersebut, yaitu 1) deskripsi tentang pendidik dan tenaga kependidikan pendidikan tinggi dan 2) analisis data pendidik dan tenaga kependidikan berdasarkan Rencana Strategi Pendidikan, Tahun 2010-2014 (Kemdiknas, 2010a).

Sesuai dengan permasalahan maka tujuan analisis SDM PT adalah untuk memahami profil SDM PT, mutu SDM PT, dan mutu PT dengan menggunakan indikator pendidikan berdasarkan Rencana Strategi, Tahun 2010-2014 (Kemdiknas, 2010a). Analisis SDM menggunakan data tahun 2009/2010 sehingga diketahui Profil SDM PT. Analisis mutu SDM PT menggunakan tujuh indikator, yaitu 1) persentase kelayakan mengajar dosen menurut status lembaga, 2) persentase dosen tetap menurut status lembaga, 3) persentase jabatan fungsional menurut status lembaga, 4) persentase pensiun dosen menurut status lembaga, jenis kelamin, perbedaan gender, dan indeks paritas gender, 5) persentase senioritas dosen menurut status 6) persentase pensiun tenaga kepen-didikan menurut status lembaga, jenis kelamin, perbedaan gender, dan indeks paritas gender, dan 7) persentase ijazah tertinggi tenaga kepen-didikan menurut status lembaga. Dari ketujuh indikator tersebut diambil lima indikator atau komposit indikator yang digunakan dalam menentukan mutu PT.

\section{Kajian Teori}

Sesuai dengan judul tulisan maka teori yang digunakan dalam analisis SDM PT ada lima, yaitu analisis, SDM, PT, data dan indikator, dan mutu SDM.

\section{Analisis}

Analisis menurut Kamus Bahasa Indonesia adalah
1) penyelidikan terhadap suatu peristiwa (karangan, perbuatan, dsb.) untuk mengetahui keadaan yang sebenarnya (sebab-musabab, duduk perkaranya, dsb.) dan 2) pemecahan persoalan yang dimulai dengan dugaan akan kebenarannya. (www.KamusBahasaIndonesia. org).

Surat Keputusan Menteri Pendidikan dan Kebudayaan Nomor 0259/U/1977 tentang Kordinasi Pengolahan Data di Departemen Pendidikan dan Kebudayaan (Depdikbud) menjelaskan tentang beberapa kegiatan yang dilakukan dalam pengolahan data di Depdikbud. Salah satu kegiatannya adalah analisis data. Analisis data didefinisikan sebagai suatu kegiatan untuk mempelajari dan meneliti data yang ada dan membuat interpretasi yang diperlukan. Oleh karena itu, terdapat tiga hal yang perlu diperhatikan dalam melaksanakan analisis data, yaitu 1) data yang dianalisis, tersedia dalam bentuk tabel, grafik atau bentuk lainnya, 2) kegiatan yang secara sadar dilakukan untuk menganalisis data, yaitu meneliti, memeriksa, mempelajari, dan membandingkan data yang satu dengan data lainnya. Hal ini berarti bahwa dalam melakukan analisis data harus terdapat data yang lebih dari satu, dan 3) interpretasi yaitu menarik simpulan dari kegiatan meneliti, memeriksa, mempelajari, dan membandingkan data yang satu dengan data lainnya dan simpulan itu perlu ditulis secara deskriptif. (Depdikbud, 1977).

Dengan demikian, analisis yang digunakan dalam penulisan ini adalah data dalam bentuk tabel dan grafik dengan mempelajari kondisi setiap variabel yang tersedia datanya dan sesuai dengan data yang akan dianalisis serta hasilnya dituliskan secara deskriptif.

\section{Sumber Daya Manusia}

Pengertian SDM adalah potensi yang terkandung dalam diri manusia untuk mewujudkan perannya sebagai makhluk sosial yang adaptif dan transformatif yang mampu mengelola dirinya sendiri serta seluruh potensi yang terkandung di alam menuju tercapainya kesejahteraan kehidupan dalam tatanan yang seimbang dan berkelanjutan. Dalam pengertian praktis seharihari, SDM lebih dimengerti sebagai bagian integral dari sistem yang membentuk suatu organisasi. 
(http://id.wikipedia.org/wiki/Sumber_daya_ manusia).

SDM pendidikan diatur dalam UU No. 20/2003 Bab XI pasal 39 sampai pasal 44. (Depdiknas, 2002a). Pasal 39 berisi tentang tenaga kependidikan yang bertugas melaksanakan administrasi, pengelolaan, pengembangan, pengawasan, dan pelayanan teknis untuk menunjang proses pendidikan pada satuan pendidikan dan pendidik merupakan tenaga profesional yang bertugas merencanakan dan melaksanakan proses pembelajaran, menilai hasil pembelajaran, melakukan pembimbingan dan pelatihan, serta melakukan penelitian dan pengabdian kepada masyarakat, terutama bagi pendidik pada perguruan tinggi.

Pasal 40 mengatur pendidik dan tenaga kependidikan untuk memperoleh penghasilan dan jaminan kesejahteraan sosial yang pantas dan memadai, penghargaan sesuai dengan tugas dan prestasi kerja, pembinaan karier sesuai dengan tuntutan pengembangan kualitas, perlindungan hukum dalam melaksanakan tugas dan hak atas hasil kekayaan intelektual, dan kesempatan untuk menggunakan sarana, prasarana, dan fasilitas pendidikan untuk menunjang kelancaran pelaksanaan tugas. Selain itu, pendidik dan tenaga kependidikan berkewajiban untuk menciptakan suasana pendidikan yang bermakna, menyenangkan, kreatif, dinamis, dan dialogis, mempunyai komitmen secara profesional untuk meningkatkan mutu pendidikan, memberi teladan dan menjaga nama baik lembaga, profesi, dan kedudukan sesuai dengan kepercayaan yang diberikan kepadanya.

Pasal 41 berisi tentang pendidik dan tenaga kependidikan yang dapat bekerja secara lintas daerah, pengangkatan, penempatan, dan penyebaran pendidik dan tenaga kependidikan diatur oleh lembaga yang mengangkatnya berdasarkan kebutuhan satuan pendidikan formal, pemerintah dan pemerintah daerah wajib memfasilitasi satuan pendidikan dengan pendidik dan tenaga kependidikan yang diperlukan untuk menjamin terselenggaranya pendidikan yang bermutu.

Pasal 42 menyatakan pendidik harus memiliki kualifikasi minimum dan sertifikasi sesuai dengan jenjang kewenangan mengajar, sehat jasmani dan rohani, serta memiliki kemampuan untuk mewujudkan tujuan pendidikan nasional. Pendidik untuk pendidikan formal pada jenjang pendidikan usia dini, pendidikan dasar, pendidikan menengah, dan pendidikan tinggi dihasilkan oleh perguruan tinggi yang terakreditasi.

Pasal 43 menyatakan tentang promosi dan penghargaan bagi pendidik dan tenaga kependidikan dilakukan berdasarkan latar belakang pendidikan, pengalaman, kemampuan, dan prestasi kerja dalam bidang pendidikan. Sertifikasi pendidik diselenggarakan oleh perguruan tinggi yang memiliki program pengadaan tenaga kependidikan yang terakreditasi.

Pasal 44 menyatakan tentang pemerintah dan pemerintah daerah wajib membina dan mengembangkan tenaga kependidikan pada satuan pendidikan yang diselenggarakan oleh Pemerintah dan pemerintah daerah. Penyelenggara pendidikan oleh masyarakat, berkewajiban membina dan mengembangkan tenaga kependidikan pada satuan pendidikan yang diselenggarakannya. Pemerintah dan pemerintah daerah wajib membantu pembinaan dan pengembangan tenaga kependidikan pada satuan pendidikan formal yang diselenggarakan oleh masyarakat.

Berdasarkan pasal-pasal di atas pada UU No. 20/2003 maka analisis yang dilakukan pada tulisan ini mencakup pendidik dan tenaga kependidikan pada PT, yaitu dosen dan tenaga kependidikan seperti administrator, pustakawan, teknisi, dan laboran.

\section{Perguruan Tinggi}

PT menurut Kamus Bahasa Indonesia adalah tempat pendidikan dan pengajaran tingkat tinggi (seperti sekolah tinggi, akademi, universitas). (www.KamusBahasaIndonesia.org).

Berdasarkan UU No. 20/2003 Bagian keempat pasal 19, pendidikan tinggi merupakan jenjang pendidikan setelah pendidikan menengah yang mencakup program pendidikan diploma, sarjana, magister, spesialis, dan doktor yang diselenggarakan oleh pendidikan tinggi. Pendidikan tinggi diselenggarakan dengan sistem terbuka. Pasal 20 menyebutkan bahwa perguruan tinggi dapat berbentuk akademi, politeknik, sekolah tinggi, institut, atau universitas. Perguruan tinggi berkewajiban menyelenggarakan pendidikan, 
penelitian, dan pengabdian kepada masyarakat. Perguruan tinggi dapat menyelenggarakan program akademik, profesi, dan/atau vokasi. (Depdiknas, 2002).

Sesuai dengan UU No. 20/2003 maka perguruan tinggi yang digunakan dalam analisis ini mencakup lima jenis lembaga, yaitu universitas, institut, sekolah tinggi, akademi, dan politeknik serta dirinci menurut status lembaga, yaitu Negeri dan Swasta.

\section{Data dan Indikator}

Data dan indikator merupakan dua konsep yang berlainan baik secara konsep maupun secara teknis, namun keduanya berkaitan sangat erat. Secara umum, menurut Kamus Bahasa Indonesia (www.KamusBahasaIndonesia.org) data adalah keterangan atau bahan nyata yang dapat dijadikan dasar kajian (analisis atau simpulan).

Secara teknis, data lebih berkaitan dengan pengumpulannya, sedangkan indikator lebih berkaitan dengan pengolahan atau hasil pengolahan. Dengan demikian, data merupakan satuan terkecil yang diwujudkan dalam bentuk angka, huruf atau simbol yang menggambarkan nilai suatu variabel tertentu sesuai dengan keadaan atau kondisi di lapangan. Angka atau huruf tersebut sering disebut sebagai data mentah atau besaran yang belum menunjukkan suatu ukuran terhadap suatu konsep atau gejala tertentu. Besaran data tersebut belum memiliki arti apa pun jika belum dilakukan pengolahan atau analisis lebih lanjut dalam bentuk informasi atau indikator. (Pusat Data dan Informasi Pendidikan, 2008).

Indikator merupakan suatu konsep dan sekaligus ukuran. Sebagai suatu konsep, indikator pendidikan merupakan besaran kuantitatif mengenai suatu konsep tertentu yang dapat digunakan untuk mengukur proses dan hasil pendidikan atau dampak dari suatu instrumen kebijakan di bidang pendidikan. Sebagai ukuran kuantitatif, indikator merupakan besaran dari suatu konsep atau gejala tertentu sebagai hasil pengolahan dari dua satuan data atau lebih dalam waktu yang bersamaan. Secara sederhana, indikator juga didefinisikan sebagai perbandingan antara dua atau lebih variabel sehingga dapat diinterpretasikan. (Depdiknas, 2002b).
Data dan indikator tidak dapat dipisahkan dan bahkan saling bergantung satu sama lain. Indikator tidak mungkin dihasilkan tanpa adanya data. Sebaliknya, data tidak memiliki acuan konseptual apa pun tanpa dilakukan pengolahan menjadi indikator. Besaran indikator ini merupakan sesuatu yang berguna karena dapat dijadikan ukuran untuk menilai kinerja pembangunan pendidikan. Indikator pendidikan berdasarkan Rencana Strategi 2010-2014 dimaksud adalah persentase dosen PT yang memiliki ijazah S2 dan yang lebih tinggi (Kemdiknas, 2010a).

Dalam analisis SDM ini digunakan data dan indikator pendidikan. Data pendidikan digunakan untuk melihat profil pendidikan tinggi pada tahun $2009 / 2010$ sedangkan indikator pendidikan digunakan untuk melakukan analisis SDM pendidikan tinggi di tingkat nasional dalam rangka peningkatan mutu pendidikan.

\section{Mutu Sumber Daya Manusia}

Sektor pendidikan mempunyai tugas untuk menyiapkan SDM. Agar SDM yang dihasilkan memenuhi syarat mutu yang pada akhirnya adalah dapat meningkatnya mutu pendidikan maka diperlukan pula sarana dan prasarana pendukungnya. Oleh karena itu, agar dapat dihasilkan SDM yang bermutu maka diperlukan dosen yang menguasai berbagai jenis dan tingkat keahlian sesuai dengan kebutuhan berbagai sektor pembangunan termasuk pembangunan pendidikan pada tingkat sekolah dasar. (Depdiknas, 2004).

Di samping itu, peningkatan mutu pendidikan merupakan tugas yang sangat kompleks karena mutu pendidikan dapat dijabarkan dalam berbagai segi. Berdasarkan teori analisis sistem (Amirin, 2001), berhasil tidaknya meningkatkan mutu pendidikan dipengaruhi oleh tiga faktor, yaitu 1) masukan pendidikan, 2) proses pendidikan, dan 3) keluaran pendidikan. Faktor masukan pendidikan dimaksud meliputi mahasiswa, sarana dan prasarana pendidikan seperti gedung, buku teks, alat peraga, dan media, mutu mengajar dosen, dan pengelola pendidikan/rektor/ direktur dan yang sejenis. Faktor proses dimaksud meliputi mutu proses belajar-mengajar, kurikulum, sistem ujian, pengelola pendidikan, masyarakat lingkungan, pembiayaan, dan kemampuan 
pemerintah (dalam hal ini adalah Kemdiknas) untuk menangani berbagai faktor penghambat negatif yang terdapat di lingkungan pendidikan. Faktor keluaran dimaksud adalah mahasiswa yang telah keluar dari sistem pendidikan yang terlihat dari banyaknya mahasiswa yang putus sekolah dan belum semua mahasiswa pada tingkat tertinggi pada masing-masing jenjang pendidikan menjadi lulusan atau lulus dengan waktu yang lebih panjang dari ketentuan yang berlaku. Ketiga faktor di atas pada umumnya dilaksanakan untuk mengantisipasi dan menangani berbagai persoalan yang mempengaruhi sistem pendidikan. Namun, tanpa mengabaikan peranan dari faktor penting lainnya dan berdasarkan pada berbagai studi/penelitian telah ditemukan bahwa mutu dosen merupakan faktor yang paling dominan dalam menentukan mutu pendidikan.

Berdasarkan uraian di atas, dapat dikatakan bahwa dosen yang bermutu adalah dosen yang mampu mendidik dan mengajar mahasiswa secara efektif sesuai dengan keterbatasan sumber daya dan lingkungannya yang ada serta prestasi mahasiswa yang tinggi dilihat dalam nilai IPK Iulusan.

Berdasarkan UU 14/2005 (Depdiknas, 2005), dosen adalah pendidik profesional dan ilmuwan dengan tugas utama mentransformasikan, mengembangkan, dan menyebarluaskan ilmu pengetahuan, teknologi, dan seni melalui pendidikan, penelitian, dan pengabdian kepada masyarakat. Selain itu, akuntabilitas dosen bisa dilihat dari empat pilar profesionalisme guru, yaitu kemampuan profesional, kemampuan pedagogis, kepribadian, dan sisi sosial. Kemampuan profesional dosen artinya menguasai materi kuliah walaupun dosen bukan satu-satunya sumber pengetahuan. Kemampuan pedagogis dosen tidak dilakukan supervisi karena bukan merupakan prioritas sehingga mahasiswa menjadi pengawas kinerja dosen dalam kemampuan mengajar. Kepribadian dosen yang baik disejajarkan dengan ketaatan beragama. Sisi sosial dosen artinya dosen harus peka pada isu-isu mutakhir di masyarakat melalui media seperti internet maupun televisi. (Widiyanto, 2011).

Sesuai dengan jenis indikator yang disajikan dalam penulisan ini dan dengan menggunakan UU 14/2005 maka mutu dosen PT juga dapat dianalisis sesuai indikator pendidikan tentang mutu PT serta disesuaikan dengan data yang tersedia.

\section{Metodologi}

Metode penelitian yang digunakan dalam analisis SDM PT adalah studi dokumentasi dan survai. Studi dokumentasi menggunakan dua jenis, yaitu 1) studi tentang data base PT yang tersedia di PDSP dan 2) studi kepustakaan tentang PT seperti Statistik Pendidikan Tinggi 2009/2010 (Kemdiknas 2010b), Profil Pendidikan Tinggi PT (PSP, 2009), dan Perkembangan Pendidikan Tinggi (PSP, 2010) sedangkan survai dilakukan dengan mengunjungi PTN dan Kopertis.

\section{Indikator Pendidikan Berdasarkan Rencana Strategi 2010-2014}

Berdasarkan Renstra 2010--2014 (Kemdiknas, 2010a) maka indikator yang digunakan dalam melakukan analisis SDM PT adalah juga berdasarkan misi lima K, yaitu ketersediaan layanan, keterjangkauan layanan, kualitas dan relevansi layanan, kesetaraan layanan, dan kepastian/ keterjaminan layanan. Dari misi lima K hanya diambil satu misi, yaitu Misi ke-3 kualitas dan relevansi layanan pendidikan. Namun, dalam analisis ini hanya digunakan kualitas layanan pendidikan yang dihasilkan dari data yang tersedia pada data base maupun dari Statistik PT, Tahun 2009/2010 (Kemdiknas, 2010a). Disebut data base PT karena data tersebut belum pernah dipublikasikan sedangkan disebut statistik PT adalah data yang dipublikasikan setiap tahun oleh PDSP.

Indikator kualitas layanan pendidikan yang dihasilkan adalah tujuh jenis indikator, yaitu 1 ) Kelayakan mengajar dosen, 2) Persentase dosen tetap, 3) Persentase jabatan fungsional dosen, 4) Persentase pensiun dosen, 5) Persentase senioritas dosen, 6) Persentase pensiun tenaga kependidikan, dan 7) Persentase ijazah tenaga kependidikan. (Pusat Statistik Pendidikan, 2009).

\section{Cara Menghitung Indikator}

Untuk memahami cara penghitungan indikator yang terkait dengan analisis SDM PT maka indikator layanan pendidikan menggunakan tujuh jenis dengan menjelaskan pengertian, variabel 
data, rumusan dan arti nilai masing-masing indikator.

\section{Persentase Kelayakan Mengajar Dosen}

Persentase kelayakan mengajar dosen adalah perbandingan antara dosen yang layak mengajar dengan jumlah dosen di setiap jenis atau status lembaga. Layak mengajar dosen dimaksud dalam penulisan ini adalah dosen yang memiliki ijazah S2 ke atas. Layak mengajar dosen seharusnya dirinci menjadi dua, yaitu menurut program diploma dan S1 dengan program pascasarjana. Dosen untuk mengajar di program diploma dan S1 adalah mereka yang berijazah S2 ke atas sedangkan dosen program pascasarjana adalah mereka yang berijazah S3. Namun, dalam analisis ini hanya digunakan ijazah S2 ke atas.

Variabel data jenis indikator ini adalah dosen menurut jenis ijazah tertinggi yang dimiliki seperti S1, S2, S3, dan Profesi.

Rumus yang digunakan adalah:

\begin{tabular}{|ll} 
& \multicolumn{1}{l}{$\begin{array}{l}\text { Jumlah Dosen Ber- } \\
\text { ijazah S2 ke atas }\end{array}$} \\
$\begin{array}{l}\text { Kelayakan = } \\
\text { Dosen }\end{array}$ & $\begin{array}{l}\text { Jumlah Dosen } \\
\text { Seluruhnya }\end{array}$
\end{tabular}

Besarnya nilai menunjukkan besarnya dosen yang layak mengajar di setiap lembaga. Makin besar nilai di suatu lembaga berarti dosen yang layak mengajar tersebut makin besar pula. Sebaliknya, makin kecil nilainya berarti dosen yang layak mengajar makin kecil. Idealnya, dosen yang layak mengajar adalah $100 \%$ berarti semua dosen memiliki ijazah yang telah sesuai dengan ketentuan berdasarkan UU No.14/2005. (Depdiknas, 2005).

\section{Persentase Dosen Tetap}

Persentase dosen tetap adalah perbandingan antara dosen tetap dengan jumlah dosen di setiap jenis atau status lembaga. Yang dimaksud dengan dosen tetap adalah dosen yang memiliki surat keputusan (SK) menjadi dosen tetap di suatu lembaga.

Variabel data jenis indikator ini adalah dosen menurut status kepegawaian seperti dosen tetap dan tidak tetap.
Rumus yang digunakan adalah:

Jumlah Dosen Tetap
\% Dosen Tetap $=$ Jumlah Dosen
Seluruhnya

Besarnya nilai menunjukkan besarnya dosen tetap di setiap lembaga. Makin besar nilai di suatu lembaga berarti dosen tetap tersebut makin besar pula. Sebaliknya, makin kecil nilainya berarti makin kecil dosen tetapnya. Idealnya, dosen yang tetap adalah $100 \%$ sehingga dosen dapat mengajar dengan lebih baik karena hanya mengajar di satu tempat.

\section{Persentase Jabatan Fungsional Dosen}

Persentase jabatan fungsional dosen adalah perbandingan antara salah satu jenis jabatan fungsional yang sesuai dengan SK yang dimiliki dengan jumlah dosen di setiap jenis atau status lembaga.

Variabel data jenis indikator ini adalah dosen menurut jenis jabatan fungsional seperti asisten, lektor, lektor kepala, dan guru besar.

Rumus yang digunakan adalah:

Jumlah Dosen JF
J Dosen JF =
Jumlah Dosen Seluruhnya

Keterangan:

$\mathrm{JF}=$ jabatan fungsional seperti asisten, lektor, lektor kepala, dan guru besar.

Besarnya nilai menunjukkan besarnya porsi jenis jabatan fungsional dosen di setiap lembaga. Makin besar nilai jabatan guru besar di suatu lembaga berarti jenis jabatan fungsional tertentu dosen di lembaga tersebut makin besar pula. Sebaliknya, makin kecil nilai jabatan asisten berarti makin baik. Hal ini menunjukkan dosen makin berkualitas sehingga jabatan fungsionalnya makin meningkat. Belum ada ketentuan berapa nilai yang ideal.

\section{Persentase pensiun dosen}

Persentase pensiun dosen adalah perbandingan antara dosen yang akan pensiun dengan jumlah 
dosen di setiap jenis atau status lembaga. Pensiun dosen dihitung dari usia dosen di atas 59 tahun.

Variabel data jenis indikator ini adalah dosen menurut kelompok usia seperti usia di bawah 59 tahun dan di atas 59 tahun.

Rumus yang digunakan adalah:

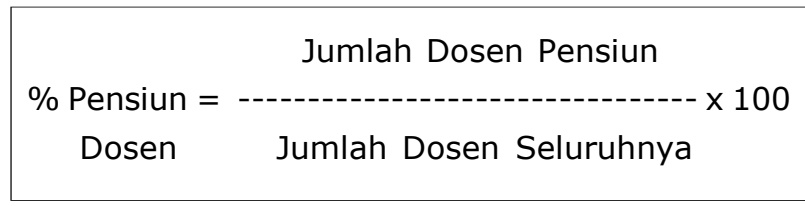

Besarnya nilai menunjukkan besarnya dosen yang akan pensiun di setiap lembaga. Makin besar nilai di suatu lembaga berarti dosen yang akan pensiun lembaga tersebut makin besar pula. Belum ada ketentuan berapa nilai yang ideal. Namun, dengan mengetahui dosen yang akan pensiun dapat direncanakan penggantian dosen tersebut sehingga tidak terjadi kesenjangan dosen yang ada.

\section{Persentase Senioritas Dosen}

Persentase senioritas dosen adalah perbandingan antara dosen yang telah senior dengan jumlah dosen di setiap jenis atau status lembaga. Dosen yang senior adalah dosen yang telah mengajar lebih dari 20 tahun.

Variabel data jenis indikator ini adalah dosen menurut kelompok masa kerja seperti 20 tahun atau kurang dan lebih dari 20 tahun.

Rumus yang digunakan adalah:

\% Senioritas $=$
Dosen

Besarnya nilai menunjukkan besarnya dosen yang senior di setiap lembaga. Makin besar nilai di suatu lembaga berarti dosen yang senior tersebut makin besar pula. Banyaknya dosen senior dapat menunjukkan mutu dosen tersebut karena sudah berpengengalaman mengajar. Belum ada ketentuan nilai yang ideal.

\section{Persentase pensiun tenaga kependidikan}

Persentase pensiun tenaga kependidikan adalah perbandingan antara tenaga kependidikan yang akan pensiun dengan jumlah tenaga kependidikan di setiap jenis atau status lembaga. Pensiun tenaga kependidikan dihitung dari usia tenaga kependidikan di atas 55 tahun.

Variabel data jenis indikator ini adalah jumlah tenaga kependidikan menurut kelompok usia kurang dari 56 tahun dan 56 tahun dan yang lebih tinggi.

Rumus yang digunakan adalah:

\% Pensiun TK $=\frac{\text { Jumlah TK Pensiun }}{\text { Jumlah TK Seluruhnya }}$

Besarnya nilai menunjukkan besarnya tenaga kependidikan yang akan pensiun di setiap lembaga. Makin besar nilai di suatu lembaga berarti tenaga kependidikan yang akan pensiun di lembaga tersebut makin besar pula. Belum ada ketentuan nilai yang ideal.

\section{Persentase Ijazah Tenaga Kependidikan}

Persentase ijazah tenaga kependidikan adalah perbandingan antara salah satu tingkat pendidikan tertinggi tenaga kependidikan dengan jumlah tenaga kependidikan di setiap status lembaga.

Variabel data jenis indikator ini adalah jumlah tenaga kependidikan menurut tingkat pendidikan tertinggi yang diperoleh seperti SD, SMP, SM, Diploma, S1, dan Pascasarjana.

Rumus yang digunakan adalah:

Jumlah TK TP
\% TK TP $=$ Jumlah TK Seluruhnya

Keterangan:

$\mathrm{TP}=$ tingkat pendidikan yaitu SD, SMP, SM, Diploma, S1, dan Pascasarjana

Besarnya nilai menunjukkan besarnya porsi tingkat pendidikan tenaga kependidikan di setiap lembaga. Makin besar nilai di suatu lembaga berarti makin besar tingkat pendidikan tenaga kependidikan di lembaga tersebut. Kondisi yang terbaik bila tenaga kependidikan yang berijazah pascasarjana paling besar. Sebaliknya, tenaga kependidikan yang berijazah SD makin kecil akan menunjukkan mutu pendidikan. Belum ada ketentuan nilai yang ideal. 


\section{Teknik Analisis}

Teknik analisis yang digunakan dalam analisis SDM PT, Tahun 2009/2010 adalah analisis deskriptif dengan sajian data dalam bentuk tabel dan grafik sederhana sehingga memudahkan bagi pembaca untuk memahami sajian. Analisis SDM PT mencakup profil SDM PT dan indikator pendidikan berdasarkan pada Rencana Strategi Pendidikan 2010-2014 pada misi ke-3 tentang kualitas layanan pendidikan yang menggunakan tujuh jenis indikator. Dari tujuh indikator tersebut digunakan lima indikator komposit untuk menentukan mutu pendidikan PT.

\section{Hasil dan Bahasan \\ Profil SDM Pendidikan Tinggi}

Profil SDM pendidikan tinggi dimaksud adalah penjelasan data SDM PT pada tahun 2009/2010. Seperti yang telah dijelaskan sebelumnya, SDM PT yang dimaksud terdiri dari pendidik dan tenaga kependidikan. Pendidik pada PT disebut dosen sedangkan tenaga kependidikan pada PT disebut bukan tenaga pengajar yang terdiri dari tenaga administrasi, pustakawan, teknisi, dan laboran.
Untuk membahas profil SDM PT maka perlu diketahui pula tentang jumlah lembaga dan mahasiswa PT karena SDM PT tidak bisa berdiri sendiri tanpa adanya lembaga dan mahasiswa PT.

Berdasarkan Tabel 1 diketahui adanya SDM PT terkait dengan lembaga dan mahasiswa yang ada. Jumlah PT sebanyak 3.011 dengan rincian 83 PT Negeri dan 2.928 PT Swasta. Jumlah mahasiswa mencapai 4.337.039 dengan rincian di PT Negeri sebesar 1.804 .761 orang dan PT Swasta sebesar 2.532.278 orang. Jumlah dosen sebesar 233.390 orang dengan rincian 65.751 di PT Negeri dan 167.639 di PT Swasta. Jumlah PT terbesar dari universitas sebesar 460 lembaga dan terkecil dari institut sebesar 53 lembaga. Jumlah mahasiswa PT terbesar juga dari universitas sebesar 3.027 .650 orang dan terkecil pada Politeknik sebesar 115.659 orang. Sesuai dengan besarnya PT pada universitas maka jumlah dosen terbesar juga pada universitas sebesar 136.878 orang dan terkecil pada institut sebesar 9.737 orang.

Dari sejumlah dosen PT sebesar 233.390 orang yang terdapat pada Tabel 2 maka dosen

Tabel 1. Jumlah Lembaga, Mahasiswa, dan Dosen PT menurut Jenis Lembaga Tahun 2009/2010

\begin{tabular}{|c|c|c|c|c|c|c|c|}
\hline No. & Variabel & Univers itas & Ins titut & ST & Akademi & Politeknik & Jumlah \\
\hline \multirow[t]{3}{*}{1} & Lembaga & 460 & 53 & 1,316 & 1,015 & 167 & 3,011 \\
\hline & Negeri & 48 & 6 & 2 & 0 & 27 & 83 \\
\hline & S was ta & 412 & 47 & 1,314 & 1,015 & 140 & 2,928 \\
\hline \multirow[t]{3}{*}{2} & Mahas is wa & $3,027,650$ & 186,823 & 754,419 & 252,488 & 115,659 & $4,337,039$ \\
\hline & Negeri & $1,680,370$ & 66,107 & 1,688 & 0 & 56,596 & $1,804,761$ \\
\hline & S was ta & $1,347,280$ & 120,716 & 752,731 & 252,488 & 59,063 & $2,532,278$ \\
\hline \multirow[t]{3}{*}{3} & Dosen & 136,878 & 9,737 & 53,206 & 21,631 & 11,938 & 233,390 \\
\hline & Negeri & 55,048 & 4,021 & 469 & 0 & 6,213 & 65,751 \\
\hline & S was ta & 81,830 & 5,716 & 52,737 & 21,631 & 5,725 & 167,639 \\
\hline
\end{tabular}

Tabel 2. Dosen PT menurut Ijazah dan Jabatan Fungsional Tahun 2009/2010

\begin{tabular}{|c|c|c|c|c|c|c|c|}
\hline & & \multicolumn{6}{|c|}{ ljazah } \\
\hline \multicolumn{2}{|c|}{ Dos en $P T$} & S 1 & S 2 & S 3 & $S p$ & sialis & Jum Iah \\
\hline \multicolumn{2}{|c|}{ Jum lah } & 145,529 & 76,090 & 9,969 & & 1,802 & 233,390 \\
\hline$a$ & Negeri & 18,836 & 35,731 & 9,721 & & 1,463 & 65,751 \\
\hline \multirow[t]{2}{*}{ b. } & S w a s ta & 126,693 & 40,359 & 248 & & 339 & 167,639 \\
\hline & & \multicolumn{6}{|c|}{ Jabatan Fungsional } \\
\hline \multicolumn{2}{|c|}{ Dos en PT } & As is te $n$ & Lektor & Lektor Kep & Gurc & Besar & Jum Iah \\
\hline \multicolumn{2}{|c|}{ Jum lah } & 87,098 & 85,549 & 52,369 & & 8,374 & 233,390 \\
\hline$a$ & Negeri & 18,910 & 21,292 & 22,380 & & 3,169 & 65,751 \\
\hline $\mathrm{b}$ & S w a s ta & 68,188 & 64,257 & 29,989 & & 5,205 & 167,639 \\
\hline
\end{tabular}




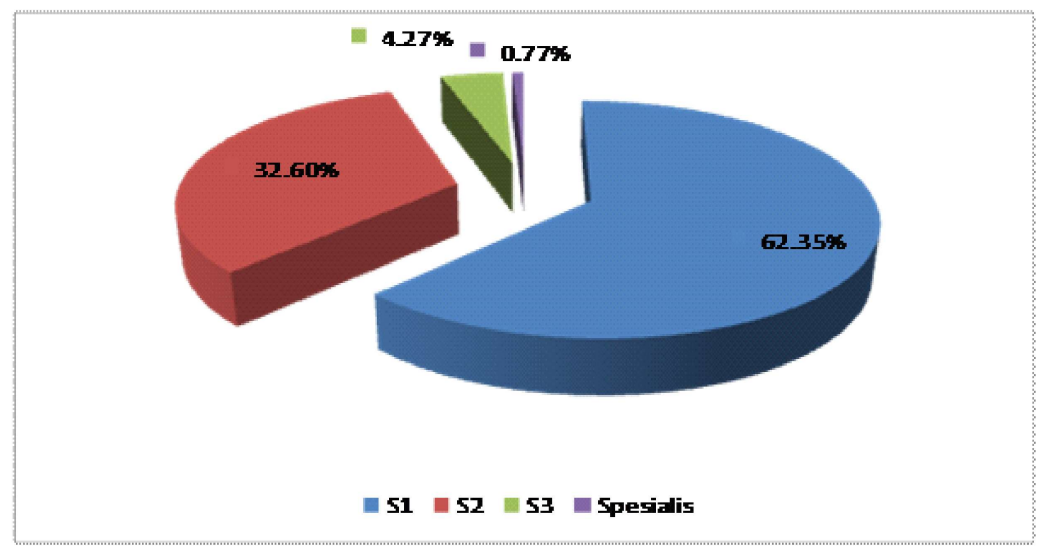

Grafik 1. Dosen menurut Ijazah Tertinggi

Tahun 2009/2010

berijazah S1 yang terbesar (145.529 orang) dan spesialis yang terkecil (1.802 orang). Untuk dosen PT Negeri yang terbesar berijazah S2 (35.731 orang) dan PT Swasta berijazah S1 (126.693 orang). Dosen yang memiliki fungsional sebagai asisten yang terbesar (87.098 orang) dan guru besar yang terkecil (8.374 orang). Untuk dosen PT Negeri yang terbesar Lektor Kepala (22.380 orang) dan PT Swasta asisten (68.188 orang).

Dari sejumlah dosen PT sebesar 233.390 orang yang terdapat pada Tabel 3 maka dosen laki-laki sebesar 153.293 orang lebih besar daripada dosen perempuan sebesar 80.097 orang. Hal yang sama untuk PT Negeri dan PT Swasta dosen laki-laki lebih besar daripada dosen perempuan masing-masing 43.185 orang dan 22.566 orang di PT Negeri dan 110.108 orang dan lembaga, masing-masing sebesar 11,232 orang dan 6.241 orang di PT Negeri dan 10.025 orang dan 5.793 orang di PT Swasta. Hal ini menunjukkan perempuan yang bekerja atau berada di PT sangat sedikit jika dibandingkan dengan laki-laki.

\section{Peningkatan Mutu Pendidikan Tinggi}

Indikator kualitas layanan PT ada tujuh jenis, yaitu kelayakan dosen mengajar, persentase dosen tetap, persentase jabatan fungsional dosen, persentase pensiun dosen, persentase senioritas dosen, persentase pensiun tenaga kependidikan, dan persentase ijazah tenaga kependidikan. Dengan demikian, dapat dinyatakan bahwa kondisi yang baik dari ketujuh indikator tersebut menunjukkan peningkatan mutu pendidikan.

Indikator kelayakan mengajar yang terdapat

Tabel 3. Jumlah Dosen dan Tenaga Kependidikan PT dan Jenis Kelamin Tahun 2009/2010

\begin{tabular}{|c|c|c|c|c|}
\hline No & Va riabel & Laki2 & Perempuan & Jumlah \\
\hline \multirow[t]{3}{*}{1} & Dosen menurut Jenis Kelamin & 153,293 & 80,097 & 233,390 \\
\hline & Negeri & 43,185 & 22,566 & 65,751 \\
\hline & \begin{tabular}{|l|l} 
b. & S was ta \\
\end{tabular} & 110,108 & 57,531 & 167,639 \\
\hline \multirow[t]{3}{*}{2} & $\begin{array}{l}\text { Tenaga Kependidikan menurut } \\
\text { Jenis Kelamin }\end{array}$ & 21,257 & 12,034 & 33,291 \\
\hline & Negeri & 11,232 & 6,241 & 17,473 \\
\hline & S wasta & 10,025 & 5,793 & 15,818 \\
\hline
\end{tabular}

57.531 orang di PT Swasta. Seperti halnya dosen maka tenaga kependidikan sejumlah 33.291 orang dengan rincian laki-laki sebesar 21.257 orang juga lebih besar daripada perempuan sebesar 12.034 orang. Tenaga kependidikan menurut status pada Tabel 4 menunjukkan bahwa dosen yang layak mengajar hanya sebesar $37,65 \%$ sangat kecil. Hal ini terjadi karena PT Swasta hanya sebesar $24,43 \%$ sangat kecil jika dibandingkan dengan PT Negeri sebesar 71,35\%. Idealnya 
dosen yang layak mengajar sebesar $100 \%$, oleh karena itu masih diperlukan peningkatan kualifikasi dosen menjadi S2 sebesar $62,35 \%$. Kondisi PT Negeri lebih bagus daripada PT Swasta karena yang layak mengajar sebesar $71,35 \%$ profesor adalah jabatan fungsional tertinggi bagi dosen yang masih mengajar di lingkungan satuan pendidikan tinggi. (Depdiknas, 2005). Berdasarkan data yang ada, dosen yang paling besar adalah asisten sebesar $37,32 \%$ dan terkecil guru besar

Tabel 4. Kelayakan Mengajar Dosen dan \% Dosen Tetap PT menurut Status Lembaga Tahun 2009/2010

\begin{tabular}{|c|c|c|c|}
\hline \multirow{3}{*}{\begin{tabular}{|l|} 
No. \\
1
\end{tabular}} & \multirow{2}{*}{\begin{tabular}{|l|} 
J enis Indikator \\
Kelayakan Mengajar \\
\end{tabular}} & \multicolumn{2}{|c|}{ Variabel Pendidikan } \\
\hline & & Layak & Tak Layak \\
\hline & Rata-rata & 37.65 & 62.35 \\
\hline & \begin{tabular}{|l|l|} 
a. & Negeri \\
\end{tabular} & 71.35 & 28.65 \\
\hline & \begin{tabular}{|l|l|} 
b. & S wasta \\
\end{tabular} & 24.43 & 75.57 \\
\hline \multirow[t]{4}{*}{2} & $\%$ Dosen Tetap & Tetap & Tak Tetap \\
\hline & Rata-rata & 67.82 & 32.18 \\
\hline & \begin{tabular}{|l|l|} 
a. & Negeri \\
\end{tabular} & 95.53 & 4.47 \\
\hline & S wasta & 56.95 & 43.05 \\
\hline
\end{tabular}

lebih besar daripada yang belum layak sebesar $28,65 \%$. Oleh karena itu, penyetaraan dosen PT Negeri hanya $28,63 \%$. Kondisi PT Swasta yang layak mengajar hanya $24,43 \%$ lebih kecil daripada yang tidak layak mengajar sebesar $75,57 \%$. Dengan demikian, dapat dikatakan mutu dosen PT masih sangat memprihatinkan, apalagi dosen PT Swasta.

Besarnya kelayakan mengajar dosen ternyata tidak sebanding dengan dosen dengan status kepegawaian tetap. Dosen tetap sebesar $67,82 \%$ lebih besar daripada dosen tidak tetap sebesar $32,18 \%$. Dosen tetap menunjukkan mutu yang lebih baik karena dosen tidak mengajar di banyak PT. Kondisi yang sebanding untuk PT Negeri banyak dosen yang layak mengajar juga banyak dosen tetapnya sebesar $95,53 \%$ dan yang tidak tetap sebesar $4,47 \%$. Sebaliknya, dosen tetap PT Swasta sebesar $56,95 \%$ sedikit lebih besar daripada dosen tidak tetap sebesar 43,05\%.

Berdasarkan Tabel 5 diketahui besarnya jabatan fungsional dosen PT. Guru besar atau sebesar 3,59\%. Kondisi PT Negeri lebih baik dengan dosen jabatan lektor kepala yang terbesar sebesar 34,04\% dan terkecil juga guru besar sebesar 4,82\%. Kondisi PT Swasta dengan dosen jabatan asisten yang terbesar sebesar $40,68 \%$ dan terkecil juga guru besar sebesar $3,10 \%$. Dengan melihat kondisi seperti ini maka dosen PT ternyata masih sangat kurang kualifikasinya untuk mengajar dan belum sesuai dengan UU 14/2005.

Berdasarkan Tabel 6 diketahui besarnya dosen yang akan pensiun, dosen dengan masa kerja yang cukup lama dan tenaga kependidikan yang akan pensiun. Dosen yang pensiun adalah dosen yang telah berusia lebih dari 59 tahun, dosen senior adalah dosen yang memiliki masa kerja lebih dari 20 tahun, dan tenaga kependidikan yang pensiun adalah tenaga kependidikan yang telah berusia lebih dari 55 tahun. Sesuai dengan banyaknya dosen laki-laki maka jumlah pensiun dosen laki-laki juga cukup besar sebesar $15,16 \%$ dan perempuan sebesar $8,44 \%$ sehingga

Tabel 5. Persentase Jabatan Fungsional Dosen PT menurut Status Lembaga Tahun 2009/2010

\begin{tabular}{|l|r|r|r|r|r|}
\hline J enis Indikator & \multicolumn{4}{|c|}{ Variabel Pendidikan } \\
\hline \% J abatan Fungsional & Asisten & Lektor & Lektor Kep & Guru Besar & J umlah \\
\hline Rata-rata & 37.32 & 36.65 & 22.44 & 3.59 & 100.00 \\
\hline a. $\quad$ Negeri & 28.76 & 32.38 & 34.04 & 4.82 & 100.00 \\
\hline b. $\quad$ S wasta & 40.68 & 38.33 & 17.89 & 3.10 & 100.00 \\
\hline
\end{tabular}




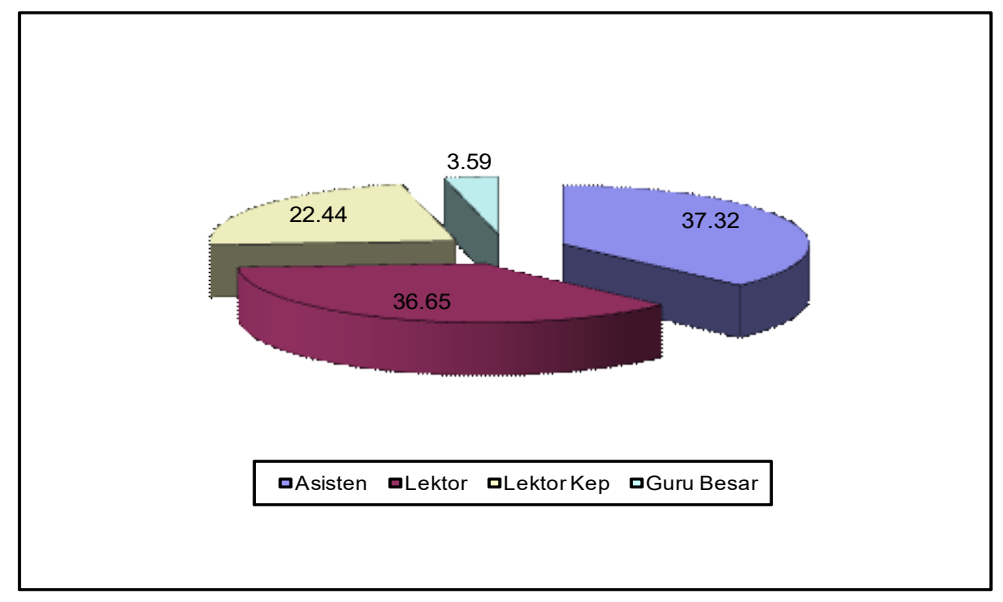

Grafik 2. Persentase Jabatan Fungsional Dosen PT

Tahun 2009/2010

Tabel 6. Persentase Pensiun dan Senioritas Dosen dan Pensiun Tenaga Kependidikan PT menurut Status Lembaga

Tahun 2009/2010

\begin{tabular}{|c|c|c|c|c|c|c|}
\hline \multirow{2}{*}{\begin{tabular}{|l} 
No. \\
1
\end{tabular}} & \multirow{2}{*}{\begin{tabular}{|l} 
Jenis Indikator \\
Pensiun Dosen
\end{tabular}} & \multicolumn{5}{|c|}{ Variabel Pendidikan } \\
\hline & & Laki2 & Perempuan & Rata 2 & $\mathrm{PG}$ & $\mathrm{IPG}$ \\
\hline & Rata-rata & 15.16 & 8.44 & 12.85 & 6.71 & 0.56 \\
\hline & \begin{tabular}{|l|l|} 
a. & Negeri \\
\end{tabular} & 14.33 & 8.84 & 12.45 & 5.49 & 0.62 \\
\hline & \begin{tabular}{|l|l|} 
b. & S wasta \\
\end{tabular} & 15.48 & 8.29 & 13.01 & 7.19 & 0.54 \\
\hline \multirow[t]{4}{*}{2} & $\%$ S enioritas Dosen & Laki2 & Perempuan & Rata 2 & $\mathrm{PG}$ & $\mathrm{IPG}$ \\
\hline & R ata-rata & 22.81 & 14.15 & 19.84 & 8.66 & 0.62 \\
\hline & \begin{tabular}{|l|l|} 
a. & Negeri \\
\end{tabular} & 40.02 & 27.82 & 35.83 & 12.20 & 0.70 \\
\hline & \begin{tabular}{|l|l|} 
b. & S wasta \\
\end{tabular} & 16.06 & 8.79 & 13.56 & 7.27 & 0.55 \\
\hline \multirow[t]{4}{*}{3} & \% Pensiun Tenaga Kependidikan & Laki2 & Perempuan & Rata 2 & $\mathrm{PG}$ & IPG \\
\hline & R a ta-rata & 5.97 & 4.73 & 5.52 & 1.24 & 0.79 \\
\hline & a. $\quad$ Negeri & 6.26 & 5.54 & 6.00 & 0.71 & 0.89 \\
\hline & b. S wasta & 5.64 & 3.85 & 4.98 & 1.79 & 0.68 \\
\hline
\end{tabular}

rata-rata sebesar 12,85\%. Kondisi di PT Negeri maupun PT Swasta agak sama dengan PT Negeri sebesar $14,33 \%$ laki-laki dan $8,84 \%$ perempuan sehingga rata-rata sebesar $12,45 \%$ sedangkan PT Swasta sebesar 15,48\% laki-laki dan 8,29\% perempuan sehingga rata-rata sebesar 13,01\%. Kondisi ini menyebabkan perbedaan gender yang cukup besar sebesar 6,71\% dan belum ada keseimbangan gender dengan nilai 0,56 jauh dari angka 1 yang seimbang.

Masih pada Tabel 6 diketahui besarnya dosen senior sebesar $19,84 \%$ dengan rincian laki-laki sebesar $22,81 \%$ dan perempuan sebesar $14,15 \%$. Hal ini sejalan dengan banyaknya dosen laki-laki dibandingkan dengan dosen perempuan. Kondisi seperti ini menyebabkan perbedaan gender sebesar $8,66 \%$ sehingga tidak ada keseimbangan dosen senior antara laki-laki dan perempuan dengan nilai 0,62 sangat jauh dari angka 1 seimbang. Dosen PT Negeri yang senior sebanyak $35,83 \%$ dengan rincian laki-laki sebesar 40,02\% dan perempuan sebesar 27,82\%. Perbedaan gender dosen PT Negeri cukup besar sebesar $12,20 \%$ sehingga tidak ada keseimbangan dosen senior antara laki-laki dan perempuan dengan nilai 0,70 jauh dari angka 1 seimbang. Hal yang sama dengan dosen PT Swasta, dosen senior sebesar $13,56 \%$ dengana rincian laki-laki senior sebesar $16,06 \%$ dan perempuan sebesar $8,79 \%$. Terjadi perbedaan gender sebesar $7,27 \%$ sehingga tidak seimbang antara laki-laki dan perempuan dengan nilai 0,55 masih jauh dari angka 1 .

Masih pada Tabel 6 diketahui besarnya tenaga kependidikan yang akan pensiun sebesar 5,52\% 
dengan rincian laki-laki sebesar $5,97 \%$ dan perempuan sebesar $4,73 \%$ dengan perbedaan gender sebesar $1,24 \%$ sehingga rasio gender sebesar 0,79 berarti belum ada keseimbangan gender dengan nilai 0,79 jauh dari angka 1 yang berarti seimbang. Kondisi di PT Negeri maupun PT Swasta agak sama dengan PT Negeri sebesar $6,26 \%$ laki-laki dan 5,54\% perempuan sehingga rata-ratanya sebesar $5,52 \%$ sedangkan PT Swasta sebesar 5,64\% laki-laki dan 3,85\% perempuan sehingga rata-rata sebesar $4,98 \%$. Kondisi ini menyebabkan perbedaan gender yang cukup besar sebesar $0,71 \%$ di PT Negeri dan terkecil berijazah SMP sebesar 6,64\%. Untuk PT Swasta, ijazah tenaga kependidikan yang terbesar juga SM sebesar $33,18 \%$ sedangkan terkecil berijazah SD.

\section{Analisis}

Indikator kualitas layanan bisa dijadikan indikator komposit untuk mengetahui mutu pendidikan tinggi pada tingkat nasional maupun provinsi. Untuk itu, dipilih 5 indikator mutu yang terkait dengan dosen dan tenaga kependidikan yang dianggap paling mempengaruhi mutu pendidikan tinggi. Dengan merata-ratakan nilai ke-5 indikator

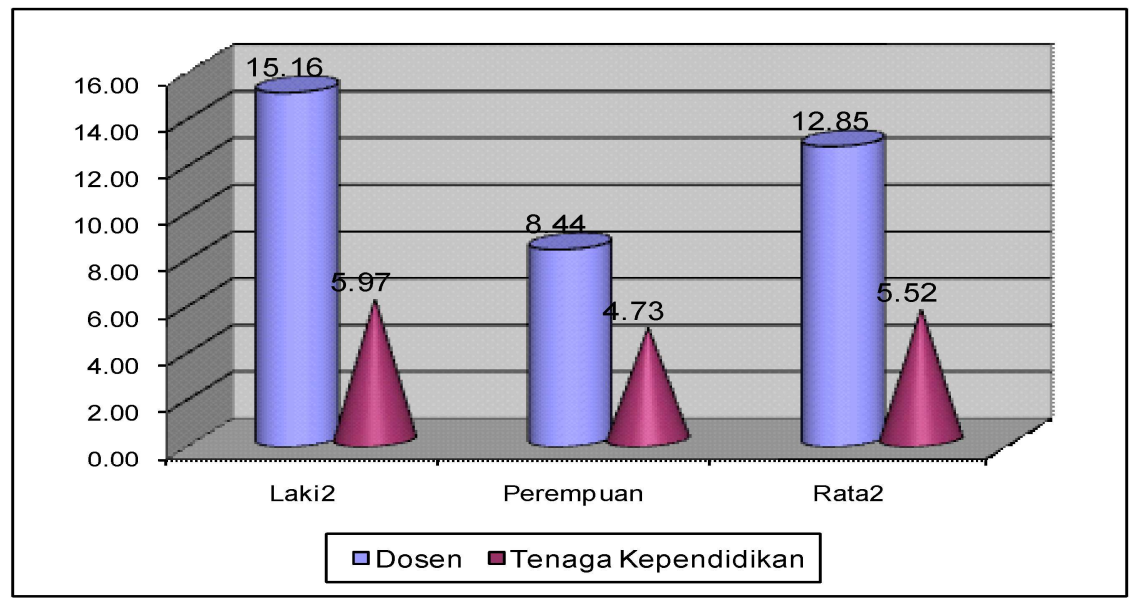

Grafik 3. Persentase Pensiun Dosen dan Tenaga Kependidikan Menurut Jenis Kelamin Tahun 2009/2010

$1,79 \%$ di PT Swasta belum ada keseimbangan gender dengan nilai 0,89 di PT Negeri dan 0,68\% di PT Swasta jauh dari angka 1 yang seimbang.

Indikator pada Tabel 7 menunjukkan persentase ijazah tenaga kependidikan menurut status lembaga. Tenaga kependidikan yang berijazah SM yang terbesar sebesar $34,82 \%$ dan terkecil berijazah SMP sebesar $6,46 \%$. Hal yang sama untuk PT Negeri ternyata ijazah tenaga kependidikan yang terbesar juga SM sebesar $36,30 \%$ dan tersebut maka diperoleh mutu pendidikan tinggi dilihat dari SDM PT. Jenis indikator mutu yang digunakan adalah persentase kelayakan mengajar dosen, persentase dosen tetap, persentase lektor kepala dan lebih tinggi, persentase senioritas dosen, dan persentase ijazah tenaga kependidikan.

Berdasarkan Tabel 8 dapat diketahui kualitas layanan PT berdasarkan lima jenis indikator komposit. Untuk menghitung kualitas PT maka

Tabel 7. Persentase Ijazah Tenaga Kependidikan PT menurut Status Lembaga Tahun 2009/2010

\begin{tabular}{|c|c|c|c|c|c|c|c|c|}
\hline & is Indikator & & & Varia & endidikar & & & \\
\hline & azah Tenaga Kependidikan & SD & S MP & SM & Diploma & $\mathrm{S} 1$ & $52 / 53$ & Jumlah \\
\hline & a-rata & 6.66 & 6.46 & 34.82 & 11.92 & 28.03 & 12.10 & 100.00 \\
\hline $\mathrm{a}$ & Negeri & 7.75 & 6.64 & 36.30 & 10.39 & 25.22 & 13.70 & 100.00 \\
\hline b & S wasta & 5.46 & 6.27 & 33.18 & 13.62 & 31.14 & 10.34 & 100.00 \\
\hline
\end{tabular}


persentase kelayakan dosen mengajar, dosen tetap, dan ijazah tenaga kependidikan menggunakan standar 100, artinya nilai terbaik adalah 100 sehingga tak perlu dilakukan konversi. Selanjutnya, persentase lektor kepala ke atas dan senioritas dosen digunakan standar $50 \%$, artinya kondisi bila dosen lektor keatas dan senior yang baik sebanyak $50 \%$ dari yang ada sehingga nilainya dibagi dengan 50 agar diperoleh konversi tertentu. Setelah kelima indikator komposit tersebut dilakukan konversi maka untuk mengetahui kualitas layanan PT, hasil kelima nilai tersebut dibagi 5. Dengan menggunakan kelima indikator komposit tersebut diperoleh rata-rata sebesar 49,85. Hal ini berarti mutu PT hanya tercapai $49,85 \%$ atau sekitar separuh.
Swasta selalu lebih besar daripada PT Negeri. Walaupun PT Swasta mencapai 97,24\% ternyata mahasiswanya hanya $58,39 \%$ dan dosennya sebesar $71,83 \%$. Hal ini menunjukkan rata-rata mahasiswa di PT Swasta lebih kecil jika dibandingkan dengan PT Negeri. Demikian juga, dosen PT Swasta. Kedua, kelayakan mengajar dosen sangat rendah sebesar $37,65 \%$ dengan kondisi PT Negeri sebesar $71,35 \%$ lebih baik daripada PT Swasta sebesar 24,43\%. Sebaliknya, dosen tetap ternyata cukup besar sebesar $67,82 \%$ dengan kondisi PT Negeri sebesar 95,53\% lebih besar daripada di PT Swasta sebesar $56,95 \%$. Ketiga, dosen dengan jabatan fungsional asisten yang terbesar sebesar $37,32 \%$ dan

Tabel 8. Kualitas Layanan PT Berdasarkan Lima Jenis Indikator Tahun 2009/2010

\begin{tabular}{|l|r|r|}
\hline Jenis Indikator & \multicolumn{1}{l|}{ Nilai } & \multicolumn{1}{l|}{ Konversi } \\
\hline$\%$ Kelayakan Mengajar Dosen (\%KMD) & 37.65 & 37.65 \\
\hline$\%$ Dosen Tetap (\%DT) & 67.82 & 67.82 \\
\hline$\%$ Lektor Kepala ke atas (\% LK+) & 26.03 & 52.05 \\
\hline$\%$ Senioritas Dosen $(\%$ SD) & 19.84 & 39.68 \\
\hline$\%$ ljazah Tenaga Kependidikan (\%ITK) & 52.06 & 52.06 \\
\hline Rata2 & & 49.85 \\
\hline
\end{tabular}

\section{Simpulan dan Saran Simpulan}

Berdasarkan hasil dan bahasan maka dapat disimpulkan 7 hal. Pertama, dari segi profil PT lembaga, mahasiswa, dan dosen ternyata PT terkecil guru besar sebesar 3,59\% sedangkan PT Negeri terbesar adalah lektor kepala sebesar 34,04\% dan PT Swasta yang terbesar adalah asisten sebesar $40,68 \%$ dan terkecil adalah guru besar sebesar 3,10\%. Keempat, dosen senior

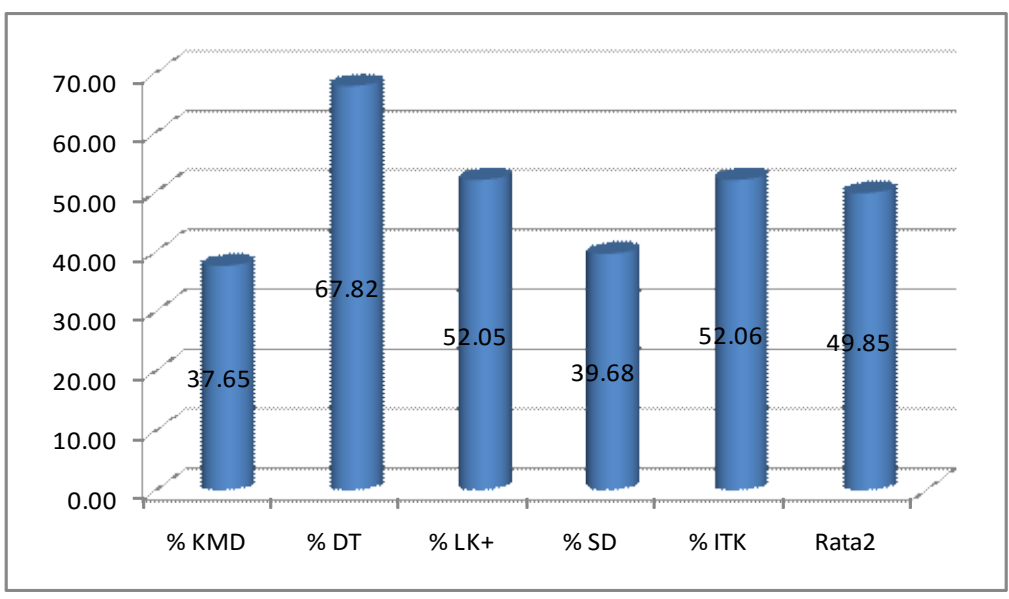

Grafik 4. Nilai Kualitas Layanan PT

Tahun 2009/2010 
sebesar 19,84\% dan lebih banyak di PT Negeri sebesar 35,83\% dan di PT Swasta sebesar $13,56 \%$. Kelima, dosen yang pensiun ternyata cukup besar 12,85\% jika dibandingkan dengan tenaga kependidikan sebesar 5,52\%. Keenam, ijazah tenaga kependidikan terbesar adalah SM sebesar 34,82\%, hal yang sama pada PT Negeri dan Swasta masing-masing sebesa 36,30\% dan $33,18 \%$. Ketujuh, berdasarkan indikator komposit maka mutu PT secara nasional hanya mencapai $49,85 \%$.

\section{Saran}

Berdasarkan simpulan di atas maka secara umum perlu dilakukan penelitian lanjutan mengenai pendataan PT khususnya SDM PT dan apakah cara penghitungan menggunakan 5 indikator komposit telah sesuai. Untuk itu, diberikan 7 saran, yaitu 1) Dengan melihat data SDM PT yang ada maka diperlukan penelitian lebih lanjut mengenai data yang ada, karena antara PT Negeri dan PT Swasta sangat besar perbedaannya baik dari segi mahasiswa maupun dosen, 2) Perlu dilakukan penelitian apakah benar dosen dan tenaga kependidikan perempuan hanya sepertiga dari jumlah data dosen seluruhnya, 3) Perlu dilakukan penelitian lebih lanjut tentang tenaga kependidikan yang ada seperti pustakawan dan laboran yang sangat kurang, 4) Perlunya peningkatan penyetaraan dosen mengajar di PT karena kelayakan dosen mengajar berijazah S2 sesuai dengan ketentuan UU No.14/2005 sangat kecil dan kondisi PT Swasta sangat lebih kecil daripada PT Negeri sehingga peningkatan mutu akan sulit dicapai, 5) Perlunya peningkatan jabatan fungsional dosen yang sangat kecil hanya asisten yang terbesar dengan PT Negeri lektor kepala dan PT Swasta asisten. Kondisi ini harus ditingkatkan apakah karena dosen malas mengurus jabatan fungsionalnya atau masalah lainnya, 6) Perlu dilakukan penelitian lebih lanjut karena dosen yang senior ternyata sangat kecil hanya $19,84 \%$, dan 7) Perlu dilakukan penelitian lebih lanjut terhadap dosen yang pensiun karena nilainya sangat tinggi sebesar $12,85 \%$ dan terjadi baik di PT Negeri maupun Swasta.

\section{Pustaka Acuan}

Amirin, Tatang M. 2001. Pokok-pokok Teori Sistem, Jakarta: PT Raja Grafindo Persada

Departemen Pendidikan dan Kebudayaan. 1977. Surat Keputusan Menteri Pendidikan dan Kebudayaan Nomor 0259/U/1977.

Departemen Pendidikan Nasional. 2002a. Undang-Undang Nomor 20, Tahun 2003 tentang Sistem Pendidikan Nasional.

Departemen Pendidikan Nasional, 2002b, Data dan Indikator untuk Penyusunan Program Pembangunan, Jakarta: Biro Perencanaan.

Departemen Pendidikan Nasional. 2004. Strategi Pendidikan Tinggi Jangka Panjang 2003-2010 Mewujudkan perguruan tinggi berkualitas. Jakarta: Direktorat Jenderal Pendidikan Tinggi

Departemen Pendidikan Nasional. 2005. Undang-Undang Nomor 14, Tahun 2005 tentang Guru dan Dosen.

http://id.wikipedia.org/wiki/Sumber daya manusia) diakses pada tanggal 25 April 2011.

Kementerian Pendidikan Nasional. 2010a. Rencana Strategis Kementerian Pendidikan Nasional 20102014.

Kementerian Pendidikan Nasional. 2010b. Statistik Perguruan Tinggi 2009/2010. Jakarta

Pusat Data dan Informasi Pendidikan. 2008. Indikator Pendidikan. Jakarta.

Pusat Statistik Pendidikan. 2009. Profil Pendidikan Tinggi 2008/2009. Jakarta.

Pusat Statistik Pendidikan. 2010. Perkembangan Pendidikan Tinggi 1998/1999-2008/2009

Widiyanto, Y.Nugroho/ Guru Bersertifikasi, di Mana Dikau? Kompas 7 Mei 2011, hal 6.

www.KamusBahasaIndonesia.org diakses pada tanggal 13 Mei 2011. 